\title{
IIIIIII創薬研究の新潮流22
}

創 薬

シリーズ(8)

\section{創薬におけるヒト肝細胞キメラマウスを用いた 薬効，毒性および薬物動態評価の有用性}

佐能 正剛, 太田 茂

要約 : 高い薬効と安全性を示す医薬品を創出するため, 医薬品候補化合物のヒトに打ける薬効, 安全性や体内 動態を予測することは重要である。ママウスにヒト肝細 胞を移植し肝臓がヒトの肝細胞で置換された「ヒト肝 細胞キメラマウス」の有用性が, これら予測モデルと して着目されている。 これまでの研究の中で, ヒト肝 細胞キメラマウスは, ヒト肝臓で生成される医薬品の ヒト代謝物や血漿中濃度推移を予測できる可能性が示 唆された。 また, 安全性評価においては薬剤誘発肝障 害の予測に, 薬理評価ではウイルス性肝炎などの薬効 モデルとしての有用性が提唱されており, 血中動態と 毒性, 薬効発現の関連性の精査や代謝物の寄与も評価 できる可能性がある。 近年は, 現状のヒト肝細胞キメ ラマウスの問題点を克服するための新しい動物モデル も開発され, 医薬品候補化合物の最適化や創薬での卜 ランスレーショナル研究に扔いて, さらに有用性が高 まることが期待される.

\section{1. 医薬品候補化合物の薬効, 安全性および体内 動態予測の重要性}

高い有効性, 安全性および良好な体内動態を示す医 薬品を創出するため, 非臨床段階において, 医薬品候 補化合物のヒトに扔ける薬効, 安全性や薬物動態を予 測することは重要である。しかしながら，世界大手製 薬メーカーの開発中止要因をまとめた報告では, 薬効 や安全性が不十分であり, 第 I, II 相試験の途中で開 発が中止になるケースは依然として多い(1)。また， その原因をみると肝毒性, 心血管系, 中枢毒性などの 毒性により臨床試験の中止や市場から撤退するケース が多く報告されている (2). 薬物動態が原因で開発が 中止になるケースは比較的少ないものの, 薬効や安全 性には, 薬物動態が関与していることも想定され, さま ざまな薬物動態予測アプローチが構築されている (3).
しかしながら，ヒト肝細胞を用いた肝クリアランスや 代謝物予測アプローチに扔いて, その予測性が十分 でない化合物も報告され $(4,5)$, 現在, ヒト化モデル 動物のような新しい薬物動態予測モデルが開発され ている。このようなモデルは, pharmacokinetics/ pharmacodynamics (PK/PD) 研究や toxicokinetics/ toxicodynamics (TK/TD) 研究に応用でき, 高い薬効 と安全性を有する医薬品の創出に貢献できるものと 考えられる。

\section{2. 薬物動態予測としてのヒト肝細胞キメラマ ウスの有用性}

\section{1）ヒト肝細胞キメラマウスの特徵}

現在, 期待されている薬物動態予測モデルマウスは 大きく 2 つのタイプに分類される(6).ひとつは, 薬 物代謝酵素やトランスポーターのヒト遺伝子を導入し た遺伝子改変モデルマウスである。 その遺伝子が全身 で発現しているため, 組織全体での評価が可能である. しかしながら, そのヒト型となっている遺伝子は限定 されたものであることからホストマウスの寄与も考慮 する必要がある。一方, 肝障害と免疫不全の性質を有 するマウスにヒト肝細胞を移植し，マウスの肝蔵がヒ トの肝細胞に置換された「ヒト肝細胞キメラマウス」 は, 肝臓でヒト型の薬物代謝酵素やトランスポーター が発現している. 肝外組織が寄与する動態はマウス型 であることを考慮しなければならないが, 肝臓で決定 される薬物動態のヒト予測に有用である. ヒト肝細胞 キメラマウスのホストマウスには, 肝障害と免疫不全 の性質を有する uPA-SCID, FRG, TK-NOG, AFC8, Alb-TRECK/SCID, FRG/NOD マウスなどが開発され, 様々な有用性が検証されてきた $(6,7)$. 質量分析装置 を用いたプロテオミクス解析により，ヒト肝細胞キメ ラマウスの肝臓に発現する薬物代謝酵素やトランス

キーワード：ヒト肝細胞キメラマウス, 薬効, 毒性, 薬物動態

広島大学大学院 医歯薬保健学研究科 ( ₹734-8553 広島市南区霞 1-2-3)

E-mail: sanoh@hiroshima-u.ac.jp＼cjkstart原稿受領日：2018 年 1 月 30 日, 依頼原稿 
ポーターの発現量を調べた研究では，概ね 4 倍以内の 範囲でヒト肝臓での発現量を反映していることが示唆 され, 定性的観点だけでなく, 定量的な薬物動態の予 測にも有用となる可能性が示唆された(8).

\section{2）ヒト肝細胞キメラマウスにおける医薬品代謝物の}

\section{予測性}

ヒト肝細胞キメラマウスにおいて, 既知の医薬品を 検証化合物として用いたヒト代謝物プロファイル研究 は多くなされ，概ねヒト代謝物の定性的予測性は良好で あることが報告されている(9)，その中で， cytochrome P450 (CYP) や UDP-glucuronosyltransferase (UGT) で 代謝される解熱鎮痛薬イブプロフェンの各代謝物の尿 中排泄率は, ヒトのプロファイルを概ね反映し, 定量 的な予測性もある可能性が示唆された(10).

製薬企業における医薬品候補化合物についてもヒト 肝細胞移植キメラマウスに投与後の血漿と尿などに おける代謝物分析と臨床試験で得られたヒト代謝物 プロファイルの比較評価が報告されている（図 1). Chymase 阻害薬である SUN13834 は，ヒトにおいてジ アゼパン環のアミド加水分解体に続く酸化代謝物 （M6）が血漿中主代謝物であるが，ヒト肝細胞キメラ マウスでも M6 は検出されており, 定性的には代謝物 プロファイルが反映していることが示された(11)。予 期せ女薬郕誘発性肝障害によって開発が中止になった ルミナコキシブのケースでは, ヒトで検出された代謝 物がヒト肝細胞移植キメラマウスにおいても見られた (12). Janus kinase 阻害薬 ASP015K は, ヒトで硫酸抱 合体（M2）が主代謝物であるが，ヒト肝細胞キメラマ ウスでも M2 が多く検出された. しかしながらヒト尿 中から検出されていた N-酸化体（M5）はヒト肝細胞 キメラマウスから検出されていない結果も見られた (13). GW695634, SB-406725, GW823093 の代謝物プ
ロファイルを比較した報告では，概ねヒトのプロファ イルを反映していたが，GW695634 のアミド加水分解， ケトン還元，グルクロン酸抱合を受けた代謝物（M7）, SB-406725 の脱水素された代謝物（M27），GW823093 のピロリジンの酸化，グルクロン酸抱合，ニトリルの 加水分解，環化された代謝物（M21，M22）は，ヒト では検出された代謝物であったものの，コントロール マウスに加えヒト肝細胞キメラマウスでも検出されな かった (14).このようにヒト肝細胞キメラマウスでヒ 卜特異的代謝物が検出できない代謝反応に加水分解反 応などが挙げられたが，その共通となる原因は不明で ある。 マウス肝細胞の寄与や肝外代謝の寄与が大きく, その代謝がさらに進んでしまうことによって検出され なくなった可能性も考えられる.

\section{3）Aldehyde oxidase が寄与する薬物代謝の予測性}

医薬品の化学構造が複雑化し，Fan らの報告のよう な珍しい薬物代謝酵素や代謝反応が寄与することもあ り (15), その臓器分布や活性種差の解明も必要となる。 その代謝反応のひとつに, aldehyde oxidase (AOX) に よる Bruton's tyrosine kinase 阻害薬 GDC-0834 の加水 分解反応がある (16)（図 2).AOX は, 含窒素芳香族 複素環の窒素に隣接する炭素原子の酸化に関わるなど 幅広い基質特異性があることが知られ，AOX1 から AOX4 の分子種が同定され，幅広い組織分布と顕著な 発現種差がある(17)。この特徵から，ヒトでの AOX の活性を予測することは難しいとされ，実際にいくつ かの医薬品候補化合物が Phase I で低いバイオアベイ ラビリティーにより開発が中止になった(18)。このよ うな背景から, ヒト肝細胞キメラマウスを用いた AOX で代謝される医薬品候補化合物の薬物動態予測評価が 注目されるようになった。

ヒト肝細胞キメラマウスの肝臓にはヒト型の AOX

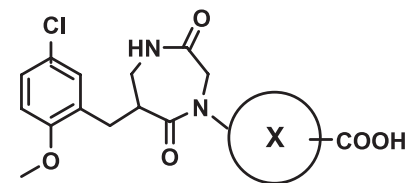

SUN13834

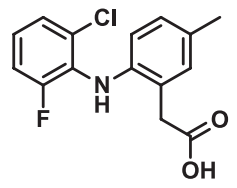

Lumiracoxib

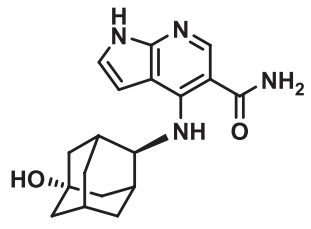

ASP015K<smiles>CCC(=O)NS(=O)(=O)c1ccc(NC(=O)COc2ccc(Cl)cc2C(=O)c2cc(Cl)cc(C#N)c2)c(C)c1</smiles>

GW695634<smiles>CC(=O)c1cc(C(=O)Nc2cc(Cl)c3c(c2Cl)CNCC3)ccc1OC(C)C</smiles>

SB-406725

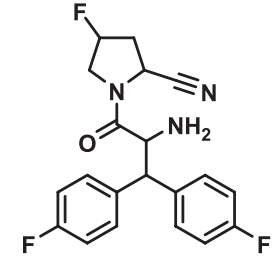

GW823093

図 1 ヒト肝細胞キメラマウスで代謝物予測性を検証した医薬品候補化合物の化学構造 


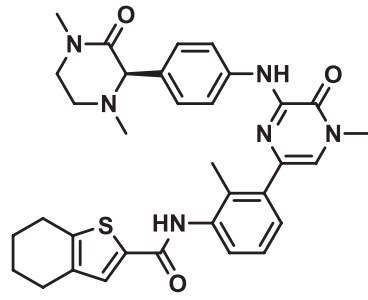

GDC-0834

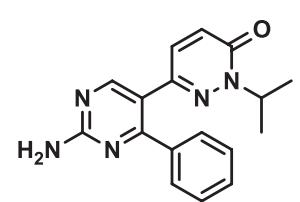

FK3453

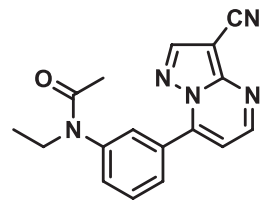

Zaleplon

図 2 ヒト肝細胞キメラマウスで AOX 代謝活性を精査した化合物の化学構造

活性がある(19)。また, AOXの基質となる睡眠導入薬 ザレプロンや医薬品候補化合物 FK3453 を検証化合物 にその代謝予測性について検討された $(20,21)$ （図 2). このときに使用されたコントロールマウスは，ラット の肝細胞を uPA/SCID マウスに移植したラット肝細胞 キメラマウスであることが特徴的である。 ラット肝細 胞キメラマウスのラット肝細胞の置換率は概ね 100\% であり (22), 創薬で汎用されるラットの薬物動態と直 接比較できる点や, AOXのようにラットとヒトで種差 がある薬剂の予測のコントロールマウスとして有用で あると考えられた。ザレプロンや FK3453 におけるヒ 卜肝細胞, ラット肝細胞キメラマウスの AOX 代謝活 性は, ヒト肝細胞キメラマウスの方が高く, 実際のヒ トとラットの関係を反映していた $(20,21)$. 一方, 上 述の GDC-0834 の AOX の寄与として考えられている 加水分解体のヒト肝細胞移植キメラマウスに打ける生 成は，ラット，イヌ，サル拉よびコントロールマウス に比べて高いことが分かり，ヒトのプロファイルに最 も近いものであった $(16,23)$ 。このことから，ヒト肝 細胞キメラマウスは, AOXの酸化や加水分解活性を反 映することが示唆された。

一方, FK3453 や GDC-0834 は臨床試験において, 低 いバイオアベイラビリティーを示した $(23,24)$. 薬効 本体が未変化体である場合は, ヒト代謝物の生成予測 だけでなく，未変化体の動態を予測できるかどうかが 創薬では重要となる.

\section{4）肝クリアランスの予測性}

Sanoh らは, 未変化体の動態予測の一環として, CYP およびnon-CYPなどさまざまな薬物代謝酵素で代謝さ れる医薬品を検証化合物とし，ヒト肝細胞キメラマウ スへ静脈内投与後のクリアランスの予測性を調べた. ヒト肝細胞キメラマウスとヒトの肝固有クリアランス を調べたところ，その相関性は $\mathrm{r}^{2}=0.754$ となり概ね 相関していることが示唆された $(25)$. その相関性に上 述の FK3453 のケースを当てはめてみると，高いクリ アランスを示す領域に位置づけされ，ヒトに打ける
高いAO 活性を予測できていたことが示唆された (9).

\section{5）PK の予測性}

さらにSanoh らは, ヒト肝細胞移植キメラマウスに 検証化合物を投与後の全身クリアランス (CLt) や分 布容積（Vdss）から single-species allometric scaling を 用いたヒトCLt およびVdss の予測性を検証した。 そ の結果, 検証化合物のうち, ジアゼパムの CLt の予測 性は大きく外れたものの, CLtは 82.4\%,Vdss は 100\% の化合物がヒトの実測值との比較において 3 倍以内の 範囲に入った．次に complex Dedrick plotを用いて血 漿中濃度推移の予測性を検証したところ，ジアゼパム は実際のヒトの血漿中濃度推移より速やかに消失する と予測されてしまう結果となったものの，残りの化合 物は概ね良好な予測性であった(26)。また, Miyamoto らは，CYPおよびnon-CYPで代謝される検証化合物を さらに増やして, 同様にSSS スケーリングを行ってい る。その結果，CLtでは， 83.3\%の化合物が，Vdssに おいては, $79.3 \%$ の化合物が 3 倍以内の予測性に入る ことが分かり (27), Sanoh らの結果 (26) を支持するも のとなった．さらには，ラットやサルの PK データか ら同様に検証した際と比べても，ヒト肝細胞キメラマ ウスの予測性が高いことが示された (27).

一方, CYPで代謝される検証化合物をヒト肝細胞 キメラマウスに投与しそのデータと physiologically based pharmacokinetic model を組み合わせることに より，ヒトにおける PKを予測するアプローチも実証 されている(28)。 またこれらの報告から $(27,28)$, 検 証化合物をカセット投与して予測評価が可能であるこ とが示唆され，その被験物質にヒトの PKが既知の陽 性化合物を入れておくことで，その予測性を確認しな がら良好な PK を示す医薬品開発化合物の絞り达みに も有用となることが期待される.

\section{6）薬物代謝酵素の遺伝多型を考慮した PK 試験}

ヒト肝細胞キメラマウスの $\mathrm{PK}$ 評価の中で, CYP の遺伝多型による $\mathrm{PK}$ の個人差も検証されている. CYP2C9 や CYP2C19 において，それぞれ3つのタイ 


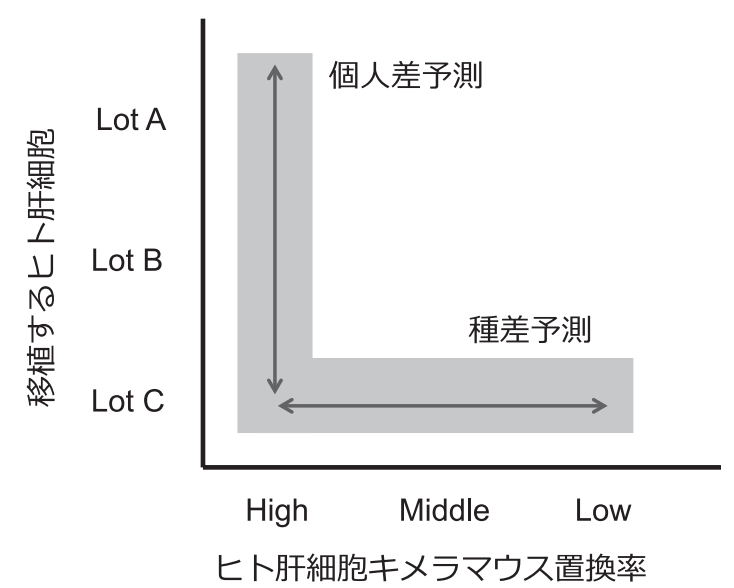

図 3 ヒト肝細胞キメラマウスを用いた薬物動態における種差, 個 人差予測のアプローチ

プの遺伝多型を有するドナー肝細胞を移植したヒト 肝細胞キメラマウスに典型基質を投与後の代謝物の生 成は，遺伝多型に応じて代謝物生成量が変化すること が実証されている (29)。医薬品候補化合物の PKの 個人差が懸念される場合, その PK の変動幅を予測す ることが重要となる。各薬物代謝酵素における poor metabolizer, extensive metabolizer など個人差を反映 する代表的なヒト肝細胞キメラマウスが構築できれば, 創薬ではさらに使いやすくなるだろう。また，臨床で の個別化薬物治療の一環として, 最適な投与量設定の 提案も可能となる。一方で, ヒト肝細胞キメラマウス の移植する肝細胞のロットによって PK の予測性が変 わる可能性も示唆されて㧍り, そのロット選択は重要 となる(図 3).

\section{7）様々なヒト肝細胞置換率を有するヒト肝細胞キメ}

\section{ラマウスを用いた PK 評価}

上述のようにジアゼパムがヒト肝細胞キメラマウス で PK予測を大きく外したのは，低，中，高置換ヒト 肝細胞キメラマウスの肝ミクロソーム画分を用いた in vitro 代謝活性の変化率から, 残存するマウス肝細胞 の寄与が大きいことがその要因だと考えられた (26). 医薬品候補化合物の PK 予測結果が妥当なものかどう かを考える上で, 置換率を変えたヒト肝細胞キメラマ ウスを使用するアプローチは有用と考えられる(9). Kitamura らは, ヒト肝細胞の置換率を 7 段階に分けた ヒト肝細胞キメラマウスを用いて， $\mathrm{AO}$ の基質となる N1-メチルニコチンアミドから 2 位酸化体と 4 位酸化 体の生成変化を追跡している. その中で, 高置換に なるにつれて，段階的に 2 位酸化体の生成が増加し， ヒトのプロファイルに近づくことが示されている(19). Kamimuraらは, glucokinase inhibitor, PF-04937319 の PK 予測研究において, $0,22.8 ， 66.4 ， 96.9 \%$ の置換率
のヒト肝細胞キメラマウスを用い，それぞれの肝クリ アランスをプロットし，想定される 100\%の置換率の ヒト肝細胞キメラマウスに扔ける值を外挿しヒト予測 に利用している $(30)$ 。このようなアプローチを用いれ ばジアゼパムのようなケースも予測可能となるかもし れない(図 3).

8）マウスス薬物代謝酵素がノックアウトされたヒト肝 細胞キメラマウスの有用性

残存するマウス肝細胞の薬物代謝の寄与を軽減さ せることを目的に，マウス cyp3aをノックアウトした マウスを掛け合わせて作成されたヒト肝細胞キメラマ ウスが開発された (31)。 ヒト型の各種薬物代謝酵素の mRNA に変化を与えず， マウスの cyp3a を欠損させて いるため, さらに予測性の高いモデル動物として期待 される。ネファゾドンを用いた検証では，ヒト肝細胞 移植キメラマウスより cyp3a ノックアウトヒト肝細胞 キメラマウスの方が，クリアランスが小さくなってい るのもこの影響によると考えられた (32)。しかしなが ら, マウス薬物代謝酵素の cyp2c55 などの発現が代償 誘導されている問題もあり (31)，さらに検証化合物を 増やして予測性を精査する必要がある。また，マウス NADPH-P450 oxidoreductase をノックアウトしたマウ スを掛け合わせたヒト肝細胞キメラマウスも開発され， マウス全体の CYP 酵素活性を失活させる意味から,こ のような課題を克服した新しいヒト肝細胞キメラマウ スとして今後の有用性が期待される(33).

\section{3. 薬剤誘発性肝毒性評価の可能性}

1）アセトアミノフェンやトログリタゾンのケース

薬剤誘発性肝障害は, 医薬品開発の中で見られる頻 度の高い毒性であり, 抗腫瘍薬, 解熱鎮痛薬, 抗ウイ ルス薬, 抗うつ薬などで多くみられる。 その中には, 薬物代謝酵素により生成された代謝物が引き金となっ て毒性発現するケースが多く知られている(34)，ヒト 肝細胞キメラマウスはヒトの肝臟の性質を有し，ヒト の代謝物を生成することから，毒性評価モデルとして， 毒性メカニズムを解明するためのモデルとしてその有 用性が着目されるようになった。これは，肝障害の性 質を有するため, コントロールマウスと比べてALTや AST が高いなど肝機能パラメータの值が異なること (35), 免疫不全の性質を有するため, 特異体質肝毒性 の原因と言われる免疫炎症系を介した毒性評価は難し いということは考慮に入れる必要があるものの, 以下 の事例のように，毒性評価の中で様々な有用性が報告 されている.

アセトアミノフェンは CYP3A4 や CYP2E1 によって 
反応性代謝物の生成の関与による肝毒性が知られてい る. ヒト肝細胞キメラマウスにアセトアミノフェンを 投与した研究では, 病理組織学的にヒト肝細胞領域に おいていくつかの病理変化が観察され，プロテオミク 又解析では脂肪酸代謝に関するタンパクの発現変化が, メタボロミクス解析では TCA サイクルに関与する内 在性物質の変化が観察された (36). さらに Yamazaki らは，肝毒性を示すトログリタゾンとフルタミドの放 射ラベル体を用いて生成する反応性代謝物に共有結合 したタンパク質の同定を行い，そのプロファイルを比 較した上で, 肝毒性予測のためのアプローチとなる可 能性を提唱した (37).

そのトログリタゾンを検証化合物としたヒト肝細胞 キメラマウスにおける毒性評価は他にもいくつか報告 されている. Schulz-Utermoehl らは, uPA/SCID マウ スを用いて, Samuelssonらは, FRG マウスのヒト肝 細胞キメラマウスを用いて， $600 \mathrm{mg} / \mathrm{kg} ， 7$ 日間反復 投与後の肝臓における毒性評価および代謝物分析を 行った $(38,39)$. 両評価ともALTやAST は顕著な上昇 は見られなかったものの, 共通してグルクロン酸抱合 体, 硫酸抱合体や酸化代謝物が検出された. Kakuni ら の報告によると，さらに高用量，長期間の $1000 \mathrm{mg} / \mathrm{kg}$, 23 日反復投与の試験において, 有意な ALT, AST の上 昇が確認され, 病理組織変化も観察された(40).ささらに ヒト胆汁排泄トランスポーター multidrug resistanceassociated protein 2 (MRP2) や bile salt export pump （BSEP）の発現量が低下する傾向も観察され (41), 、 ウス型のトランスポーターには影響を与えていないこ とも考えると, ヒト特異的な胆汁うっ滞評価にも有用 なモデルとなることも示唆された.

\section{2）薬片誘発性胆汁うっ滞肝毒性評価としての可能性}

エンドセリン受容体拮抗薬, 肺高血圧症の治療薬ボ センタンはヒトで特異的に肝毒性を示す。その要因と して胆汁排泄トランスポーターの阻害も考えられてい る. ボセンタンをヒト肝細胞キメラマウスに $160 \mathrm{mg} / \mathrm{kg}$ を 28 日間反復投与した研究では，コントロールマウ スでは見られなかったALTの上昇が確認されている. また血漿中総胆汁酸濃度も増加していた (42)。それよ りも以前の報告で，茵蔯蒿湯の成分が， NRF-2 制御に よる MRP2 の発現量を上げ, ビリルビンの胆汁排泄を 促進させる可能性をヒト肝細胞キメラマウスで実証し ている(43)。またウルソデオキシコール酸も, ヒト肝 細胞キメラマウスにおいて MRP2 の発現を上昇させ ることが報告されている(44)。このような知見を踏ま えると, ヒト肝細胞キメラマウスは, MRP2 や BSEP の機能評価や胆汁うっ滞肝毒性の評価モデルとして有
用となる可能性が考えられる.

一方，ヒト肝細胞キメラマウスの肝臟重量体重比は 通常のマウスより大きいが，その要因のひとつとして， 肝細胞の増殖を促進する胆汁酸の産生調節が異なって いることが考えられている。 ヒト肝細胞キメラマウス の胆汁酸合成に関わる CYP7A1 の発現は高く, 血中胆 汁酸濃度も高い。ヒト肝細胞キメラマウスにおいては, マウス小腸で分泌される fibroblast growth factor 15 が マウス型であるため, 肝臓のヒト CYP7A1 を制御でき ないことが原因と言われている(45-47). Chowらの 報告では，FRGNのヒト肝細胞キメラマウスはコント ロールマウスやヒトと比較して各胆汁酸の組成が異な ることも示している $(47)$.このように胆汁酸動態が実 際のヒトと異なることから, 胆汁酸うっ滞評価として のモデルとして有用であるかはさらに検証化合物を増 やしながら精査していく必要がある.

\section{3）化学物質の肝臓における発がん性評価}

Toyoda らは，1,2-ジクロロプロパンの胆管がんの原 因を解明する目的で, ヒト肝細胞キメラマウスに投与 し, その原因の可能性と考えられる毒性代謝物の胆汁 排泄を評価し，ヒトでの発がん性の原因を考察してい る(48). 高用量のフェノバルビタールによる核内受容 体 constitutively active/androstane receptor の活性化を 介した肝細胞肥大，発がん作用が知られているが，七 卜肝細胞キメラマウスにフェノバルビタールを投与し ても肝重量増加, 肝細胞増殖関連遺伝子の発現や DNA 合成に影響をほとんど与えないことが分かり，マウス とヒトでフェノバルビタールの感受性の違いがあるこ とを示唆している(49). また peroxisome proliferatoractivated receptor $\alpha$ アゴニストのフェノフィブラート をヒト肝細胞移植キメラマウスに投与した実験でも, げっ歯類では, 肝臓のペルオキシソームの増殖や肝臓 の肥大化を経て発がんを誘導することが知られている ものの, ヒト肝細胞キメラマウスではこのような現象 が観察されず種差があることが示唆された(50)。これ らは医薬品の肝細胞発がんの評価にも有用な知見と なる。

\section{4）薬剤誘発性リン脂質症評価モデルの可能性}

ヒト肝細胞キメラマウスを用いた肝毒性評価におい て, 残存するマウス肝細胞の影響がどの程度含まれて くるのかは, 評価のエンドポイントによって変わって くる．このためコントロールマウスを置くことは重要 となる。一方で, ヒト肝細胞キメラマウスの肝切片の 組織染色による肝毒性評価の中でヒト肝細胞領域とマ ウス肝細胞領域を識別することにより, 同時にその種 差をみることは可能である. Sanoh らは, 医薬品開発 
の中止要因となる毒性の一つである薬剤誘発性リン脂 質症の陽性対照, アミオダロンをヒト肝細胞キメラマ ウスに投与し，その肝切片をイメージング質量分析装 置でヒト肝細胞とマウス肝細胞に打けるアミオダロン の局在やホスファチジルコリンの局在変化を可視的に 評価した (51)。これらは，マウス肝細胞の寄与を有効 に利用した事例となり, エンドポイントが異なる評価 に拈いても有用なアプローチとなると考えられた。

\section{4. 薬効評価予測モデルとしての有用性}

\section{1） $\mathrm{B}$ 型 $\mathrm{C}$ 型肝炎ウイルス感染モデル}

ヒト $\mathrm{B}, \mathrm{C}$ 型肝炎ウイルスはヒトもしくはチンパン ジーにしか感染しない. 倫理的な問題からチンパン ジーを用いた評価は難しい中で，ヒト肝細胞キメラマ ウスは肝炎ウイルスモデルとして有用となる。 B 型 C 型肝炎ウイルス (HBV, HCV) 感染モデルは, ヒト肝 細胞キメラマウスに, 肝炎ウイルスに感染した患者の 血清や肝炎ウイルスを含む培養液上清を感染源として 接種し作製する. HCV の感染は高置換のヒト肝細胞 キメラマウスが必要であるが, HBV は, 低置換のヒト 肝細胞キメラマウスにも感染する。 HCV 感染モデル では, ペグインターフェロンアルファによって血清中 $\mathrm{HCV}$ の RNA 濃度が減少し, HBV 感染モデルでは, ペ グインターフェロンアルファやラミブジンによって 血清中 HBV の DNA 濃度が減少することも分かり,さ まざまな医薬品開発や治療戦略の確立や, ウイルスの ジェノタイプの違いにおける治療薬の感受性も評価で きることが知られている(52-54). またホストマウス の違いや移植するヒト肝細胞のロットの違いによって 医薬品の感受性も異なる可能性があり, 最適なモデル 選択の重要な情報となる(55)。 ヒト肝細胞キメラマウ スは免疫不全の性質を有しているため, 肝炎ウイルス 患者の病態を完全に模倣できていない可能性もあるも のの, 現在の治療では有効でない $\mathrm{HBV}, \mathrm{HCV}$ 肝炎患 者の新しい治療戦略の開発や, 最近では, D 型肝炎モ デルとしての可能性も提唱されており, 幅広い肝炎ウ イルス治療において, 大いに貢献できるモデルとして 期待される (56).

\section{2） PK/PD モデルとして}

$\mathrm{HCV}$ を感染させたヒト肝細胞キメラマウスの肝臓 に扔ける薬物代謝酵素や取り込み, 排泄トランスポー ターの発現量を調べた研究において, 非感染のヒト肝 細胞キメラマウスに扔ける発現プロファイルを概ね反 映していることが分かった(57)。このことは，肝炎ウ イルス患者は薬物代謝酵素やトランスポーターの発現 に影響を与えない可能性も考えられる一方で，これま
での PK 予測が非感染, 感染モデル両方を用いても行 うことができ, 肝炎治療薬の PK/PD 研究に有用とな ることを示唆する，Kamiya らは，C型肝炎治療薬 NS3-4A プロテアーゼ阻害薬テラプレビルをヒト肝細 胞キメラマウスに投与後の血漿中濃度, 肝臓中濃度の 関連性, 感染ウイルス量の減少との関連性を精査して いる. その中で, テラプレビル血漿中濃度と $\mathrm{HCV}$ の RNA 減少に相関性がみられ, 最適な投与量の推定が 可能となることが示唆された (58). 上述のように, ヒ 卜肝細胞キメラマウスは, ヒトの血漿中濃度推移も予 測できる可能性があることから，このような方法論を 組み合わせればさらに精度の高い PK/PD 研究が構築 できる可能性もある。また，NS4B タンパク質を標的 とした HCV の治療薬開発の中で, 経口吸収性が悪い リード化合物の最適化のためのプロドラッグ創製を行 い, ヒト肝細胞キメラマウスを用いた血中動態の向上 と，HCVに対する治療効果が検証された (59)。このよ うに, ヒト肝細胞キメラマウスでの $\mathrm{PK}$ 試験や感染モ デルでの薬効試験を組み合わせることで, 創薬段階に おける医薬品開発化合物の最適化にも有用であると考 えられた。

\section{3）他のモデルとしての可能性}

肝炎ウイルス感染モデル以外に, マラリア感染症モ デルやサイトメガロウイルス感染モデルとしての可能 性が報告され，ワクチンや治療薬の有効性や安全性の 評価に有用となる可能性が示唆された $(60,61)$ 。また, ヒト肝細胞キメラマウスは尿酸代謝に関わるウリカー ゼの寄与が小さいことにより血中尿酸濃度が安定して おり, ヒトを反映した高尿酸血症のモデル動物として も貢献できると考えられている(62)，さらには，メー プルシロップ疗症, クリグラー・ナジャー症候群, 尿 素サイクル異常症, 家族性肝内胆汁うっ滞, 胆道閉鎖 症の患者の肝細胞を FRG マウスに移植したヒト肝細 胞移植キメラマウスの構築が報告された (63).

以上のような考え方を応用すれば，ヒト肝細胞キメ ラマウスは, 様々な疾患モデルを作製できる可能性が あり, ヒト特異的な病態バイオマーカーの探索や新薬 の開発に貢献できることも期待される. しかしながら， キメラマウスは, 免疫不全の性質を有していることや, 非実質細胞はマウスの細胞であるため, 医薬品の作用 がこれらに関与する場合，評価には注意を有する。

\section{5. ヒト肝細胞キメラマウスにおける将来展望}

表 1 は，これまでの知見から明らかとなってきてい るヒト肝細胞キメラマウスの薬物動態, 安全性, 薬効 評価の観点から現状の有用性と課題をまとめたもので 
表 1 ヒト肝細胞キメラマウスの薬物動態, 薬理, 安全性評価における有用性と課題

\begin{tabular}{|c|c|c|c|}
\hline 評価 & 適用 & 有用性 & 課題 \\
\hline 薬物動態評価 & $\begin{array}{l}\text { 代謝物予測 } \\
\text { PK 予測 }\end{array}$ & $\begin{array}{l}\text { 毒性や薬効に寄与する活性代謝物の予測 } \\
\text { 投与量設定や PK/PD, TK/TD 研究 }\end{array}$ & 残存するマウス肝細胞や肝外組織の寄与 \\
\hline 薬効評価 & 病態モデル & $\begin{array}{l}\text { ウイルス性肝炎モデルにおいて, チンパンジーに } \\
\text { 代わる小動物での評価 } \\
\text { 病態の原因が肝臓で説明できる場合の疾患モデル } \\
\text { の開発 }\end{array}$ & 免疫不全の性質やマウス非実質細胞の影響 \\
\hline 毒性評価 & 薬剂誘発性肝障害評価 & ヒト代謝物を考慮に入れた肝毒性評価 & $\begin{array}{l}\begin{array}{l}\text { ホストマウスの肝障害や免疫不全の性質の } \\
\text { 影響 }\end{array}\end{array}$ \\
\hline
\end{tabular}

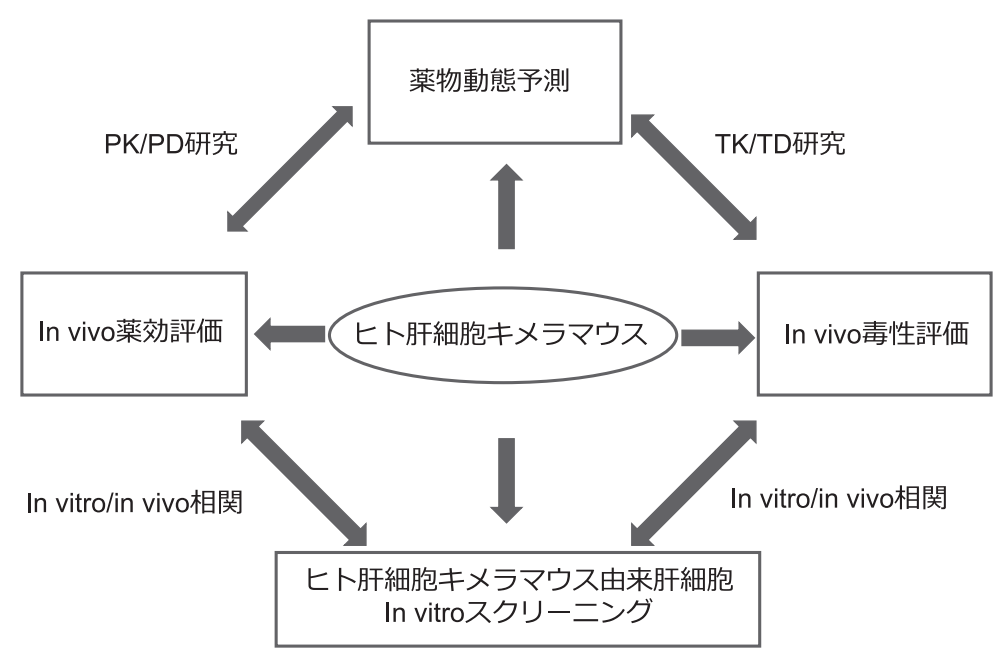

図 4 ヒト肝細胞キメラマウスを用いた創薬展開

ある．今後，このような課題を克服した別途評価系の 適用やさらに新しく改変したヒト肝細胞キメラマウス の構築と検証が必要となる。薬物動態の観点において は，ヒト肝細胞キメラマウスを用いたトランスポー ターの寄与によって動態が決定される医薬品の PK 予 測性の検証は十分でないものの, 少なくとも代謝型薬 物においては, PK 予測が可能となることが示唆され, ヒト肝細胞キメラマウスを用いて薬物動態と薬効, 毒 性を同時に評価できれば，精度の高い PK/PD や TK/ $\mathrm{TD}$ 解析が可能となる。これは, トランスレーショナ ルリサーチに貢献できるモデル動物と言える.

ヒト肝細胞キメラマウスは高価であるため, in vitro 試験の位置づけも重要となる。ヒト肝細胞移植キメラ マウスから単離した肝細胞は新鮮な状態で，また移植 した細胞数の数百倍の肝細胞を単離できるため生産性 も高い。ささらに高い薬物代謝酵素活性を維持している ことや，B型肝炎ウイルスに感染した肝細胞培養系も 構築されており, ヒト肝細胞キメラマウスの in vivo 評 価を行う前の予備評価の位置づけとして, 代謝評価や 肝炎治療薬の in vitro スクリーニングの実施や, in vitro と in vivoの相関性を評価する上においても有用
なアプローチになると考えられる $(64,65)$.

新しいヒト肝細胞キメラマウスとして, iPS由来肝 細胞や株化細胞 HepaRG 細胞を移植したマウスの有用 性も期待される $(54,66)$ 。これは, ドナー肝細胞の供 給に制限があることや, 肝細胞のロット差の問題を解 決する.また個別化薬物治療にもつながる可能性もあ る，さらには，マウスに代わるラットヒト化肝臟モデ ルが実用化されれば，創薬ではラットを使った評価が 多いことからもその有用性はさらに高まるだろう (54). ヒト肝細胞キメラマウスを用いた新規薬効モデルとし て, 毒性モデルとしての開発が同時に進めば, 肝蔵に 限定した評価となるものの, 実験動物とヒトの種差を 考慮に入れた創薬に大いに貢献できる（図 4).

著者の利益相反 : 佐能正剛, 太田 茂 (アステラス製薬株式 会社, 株式会社クラレ, 株式会社フェニクスバイオ).

\section{文献}

1) Waring MJ, et al. Nat Rev Drug Discov. 2015;14:475-486.

2) Hornberg JJ, et al. Drug Discov Today. 2014;19:1131-1136.

3) Di L, et al. Drug Metab Dispos. 2013;41:1975-1993.

4) Fagerholm U. J Pharm Pharmacol. 2007;59:803-828.

5) Dalvie D, et al. Chem Res Toxicol. 2009;22:357-368. 
6) Scheer N, et al. Drug Discov Today. 2016;21:250-263.

7) Naritomi Y, et al. Drug Metab Pharmacokinet. 2018;33:31-39.

8) Ohtsuki S, et al. Drug Metab Dispos. 2014;42:1039-1043.

9) Sanoh S, et al. Biopharm Drug Dispos. 2014;35:71-86.

10) Sanoh S, et al. Drug Metab Dispos. 2012;40:2267-2272

11) Igawa $Y$, et al. Xenobiotica. 2014;44:154-163.

12) Dickie AP, et al. Biochem Pharmacol. 2017;135:139-150.

13) Nakada N, et al. Xenobiotica. 2015;45:757-765.

14) De Serres M, et al. Xenobiotica. 2011;41:464-475.

15) Fan PW, et al. Drug Metab Dispos. 2016;44:1253-1261.

16) Sodhi JK, et al. Drug Metab Dispos. 2015;43:908-915.

17) Terao M, et al. Arch Toxicol. 2016;90:753-780.

18) Sanoh $S$, et al. Drug Metab Pharmacokinet. 2015;30:52-63.

19) Kitamura $S$, et al. Drug Metab Dispos. 2008;36:1202-1205.

20) Sanoh S, et al. Drug Metab Dispos. 2012;40:76-82.

21) Tanoue C, et al. Xenobiotica. 2013;43:956-962.

22) Utoh R, et al. Am J Pathol. 2010;177:654-665.

23) Liu L, et al. Drug Metab Dispos. 2011;39:1840-1849.

24) Akabane T, et al. Xenobiotica. 2011;41:372-384.

25) Sanoh S, et al. Drug Metab Dispos. 2012;40:322-328.

26) Sanoh S, et al. Xenobiotica. 2015;45:605-614.

27) Miyamoto M, et al. Xenobiotica. 2017;47:1052-1063.

28) Utoh M, et al. Xenobiotica. 2016;46:1049-1055.

29) $\mathrm{Hu} \mathrm{Y}$, et al. Pharmacogenet Genomics. 2013;23:78-83.

30) Kamimura H, et al. Xenobiotica. 2017;47:382-393.

31) Kato K, et al. Drug Metab Dispos. 2015;43:1208-1217.

32) Nakada N, et al. Biopharm Drug Dispos. 2016;37:3-14.

33) Barzi M, et al. Nat Commun. 2017;8:39

34) Chen M, et al. Drug Discov Today. 2011;16:697-703.

35) Tateno C, et al. Lab Invest. 2013;93:54-71.

36) Yamamoto T, et al. J Toxicol Sci. 2007;32:205-215.

37) Yamazaki H. Toxicol Res. 2015;4:106-111.

38) Schulz-Utermoehl T, et al. Xenobiotica. 2012;42:503-517.
39) Samuelsson K, et al. Xenobiotica. 2014;44:186-195.

40) Kakuni M, et al. Toxicol Lett. 2012;214:9-18.

41) Foster JR, et al. Toxicol Pathol. 2012;40:1106-1116.

42) Xu D, et al. J Pharmacol Exp Ther. 2015;352:274-280.

43) Okada K, et al. Am J Physiol Gastrointest Liver Physiol. 2007; 292:G1450-G1463.

44) Okada K, et al. Am J Physiol Gastrointest Liver Physiol. 2008; 295:G735-G747.

45) 立野知世. 生化学. 2012;84:699-706.

46) Nauglar WE, et al. Gastroenterology. 2015;149:728-740.

47) Chow EC, et al. J Pharmacol Exp Ther. 2017;360:174-191.

48) Toyoda Y, et al. Sci Rep. 2016;6:24586.

49) Yamada T, et al. Toxicol Sci. 2014;142:137-157.

50) Tateno C, et al. Toxicol Pathol. 2015;43:233-248.

51) Sanoh S, et al. J Toxicol Sci. 2017;42:589-596.

52) Chayama K, et al. J Gastroenterol Hepatol. 2011;26:13-18.

53) 加国雅和, 他. ファルマシア. 2012;48:956-958.

54) Yoshizato K, et al. Expert Opin Drug Metab Toxicol. 2013;9:14191435.

55) Kosaka K, et al. Biochem Biophys Res Commun. 2013;441:230235.

56) Kremsdorf D, et al. Curr Opin Virol. 2017;25:119-125.

57) Kikuchi R, et al. Drug Metab Dispos. 2010;38:1954-1961.

58) Kamiya N, et al. J Gen Virol. 2010;91:1668-1677.

59) Miller JF, et al. J Med Chem. 2014;57:2107-2120.

60) Kawahara T, et al. Hepatol Res. 201;43:679-684.

61) Vaughan, et al. J Clin Invest. 2012;122:3618-628

62）安西尚彦,他. Gout and Nucleic Acid Metabolism. 2008;32:13-17.

63) Gramignoli R, et al. Stem Cell Res. 2013;11:563-573.

64) Yamasaki C, et al. Drug Metab Pharmacokinet. 2010;25:539-550.

65) Ishida Y, et al. Am J Pathol. 2015;185:1275-1285.

66) Higuchi Y, et al. Xenobiotica. 2014;44:146-153.

\title{
Contribution of chimeric mice with a humanized liver to the evaluation of pharmacology, toxicity, and pharmacokinetics in drug discovery and development
}

\author{
Seigo Sanoh, Shigeru Ohta \\ Graduate School of Biomedical and Health Sciences, Hiroshima University
}

\begin{abstract}
To develop new drugs with high efficacy and safety, it is important to predict the pharmacological, toxicological, and pharmacokinetic profiles of drug candidates in humans. Chimeric mice with a humanized liver are mice in which human hepatocytes have been transplanted, such that mouse liver cells are replaced with human hepatocytes; these mice have been used as prediction models. Studies performed thus far indicate that chimeric mice with a humanized liver can be used for the prediction of human-specific metabolite formation and plasma concentration-time curves for several drugs. Furthermore, studies advocate the utility of chimeric mice with a humanized liver for modelling drug-induced hepatotoxicity and disease such as hepatitis virus infection in safety and pharmacological evaluations respectively. Taken together, these findings indicate that chimeric mice with a humanized liver can be used to evaluate the relationship between pharmacokinetics, toxicity, and efficacy; the contribution by active metabolites may also be assessed. In recent years, new and improved animal models have been developed to overcome the disadvantages of chimeric mice with a humanized liver. It is expected that their usefulness for optimization of drug candidates and translational research in drug discovery and development will further increase.
\end{abstract}

